\title{
Multi-Group Analysis: Testing Moderating Effects for the Causal Structure Model of Self-Action-Outcome (Sao Model)
}

\author{
Norida Abdullah ${ }^{1}$, Mohd Shamsuri Md Saad ${ }^{1}$, Subatira Balakrishnan ${ }^{1}$, Asiah Mohd Pilus ${ }^{1} \&$ Ahmad Tajuddin \\ Othman $^{2}$ \\ ${ }^{1}$ Centre for Languages and Human Development, Universiti Teknikal Malaysia Melaka, Melaka, Malaysia \\ ${ }^{2}$ School of Educational Studies, Universiti Sains Malaysia, Pulau Pinang, Malaysia \\ Correspondence: Norida Abdullah, Centre for Languages and Human Development, Universiti Teknikal \\ Malaysia Melaka, 76000 Durian Tunggal Melaka, Malaysia. Tel: 606-331-6927. E-mail: noridaha@utem.edu.my
}

Received: January 16, 2015 Accepted: January 28, 2015 Online Published: June 5, 2015

doi:10.5539/ass.v11n17p101 URL: http://dx.doi.org/10.5539/ass.v11n17p101

\begin{abstract}
This study focuses on testing the moderating effects based on gender, academic performance, faculty and residential setting based on Self-Action-Outcome (SAO) model that was developed by the researchers. This model examined the relationship between self-esteem, job-search intensity and career decision-making self-efficacy among undergraduate students. Several instruments were used to develop this model were, the Rosenberg Self-Esteem Scale, Job-Search Intensity Scale, and Career Decision-Making Self-Efficacy Scale. Cluster sampling procedure was used in recruiting the participants. Data were collected using a self-reported questionnaire from 678 undergraduate students and were tested with confirmatory factor analysis to obtain three best-fit measurement models from the three latent variables. The results showed that gender, academic performance, faculty and residential setting did not moderate the hypothesized SAO model which means that the hypothesized SAO model is a good model for undergraduate students. Implications of the findings for social work practice such as guidance counsellor, research, theory, policy and education were also discussed.
\end{abstract}

Keywords: Multi-group analysis, moderating effects, SAO model, undergraduate students

\section{Introduction}

In the twenty-first century workplace, possessing a bachelor degree is no longer the passport to secure jobs (Mazwin, 2006). Employers are increasingly looking for more than just content knowledge and hard skills; they want "work-ready" graduates with desired soft-skills. Employers worldwide have been critical about graduates and their readiness for the world of work (NCIHE, 2009). Similarly, Malaysian employers are generally not happy with the level of soft-skills possessed by graduates entering the workforce. According to Malaysian employers, Malaysian graduates normally were qualified in their area of studies, but they lacked self-confidence and skills in preparation for job-search (Zuraidah, 2008), and their main drawbacks are lack of positive attitude, confidence, and preparation for job-search (Lazaroo, 2008). In other words there has been lack of soft-skills and competency among newly graduating students (self-confidence, positive attitude, job-search preparation skills, and communication skills) in relation to employability.

These drawbacks are closely related to self-esteem, job-search behaviour and career decision-making self-efficacy as the variables involved in the present study. Self-esteem has a vast definition by different scholars. For example, self-esteem refers to an overall evaluation of oneself in either a positive or negative way and believes himself or herself to be competent and worthy of living (Ranjit, 2009). Self-esteem is also viewed as a global judgment of the worth or value of the self (Crocker, 2004). Job-search intensity is defined as the frequency whereby job seekers engage in job-search activities such as preparing a resume or contacting an employment agency (Kanfer, Wanberg, \& Kantrowitz, 2001). Career decision-making self-efficacy specifically refers to individuals' feelings of competency in their abilities for self-appraisal, gathering occupational information, selecting career goals, engaging in career planning, and problem solving when difficulties are encountered (Swanson \& D'Achiardi, 2005).

Several studies had investigated certain variables related to self-esteem (Salmero-Aro \& Nurmi, 2007; Baumeister, Campbell, Krueger, \& Vohs, 2003; Schaufeli, Martinez, Marques Pinto, Salanova, \& Bakker, 2002; 
Betz, 2004; Saks, 2005), job-search intensity (Aharon, Efrat, \& Limor, 2004; Crossley \& Stanton, 2005; Brown, Cober, Kane, Levy, \& Shalhoop, 2006; Cote, Saks, \& Zikic, 2006) and career decision-making (Feinstein-Messinger, 2007; Ennis, 2006; Montgomery, 2006; Crespin, 2006; Foster, 2005; Rowland, 2004). However, there has been little discussion about the relationship on these three variables.

Knowing about our own self (Self-knowledge), behaviour (Action) and the results (Outcome) is very important for the job seekers especially for the undergraduate students before they enter the job market (Zunker 2006). Therefore, this study has two folds objectives, firstly to examine the relationship between self-esteem (Self-knowledge), job-search intensity (Action), and career decision-making (Outcome) among undergraduate students and propose a model of self-action-outcome (SAO) for the students. To validate the SAO model, testing moderating effects were used based on gender, academic performance, faculty and residential setting. Objective of the research and the hypotheses tested are as follows:

RO1: What is the proposed model of SAO?

H1: Gender moderates the causal structure of the SAO model.

H2: Academic Performance moderates the causal structure of the SAO model.

H3: Faculty moderates the causal structure of the SAO model.

H4: Residential setting moderates the causal structure of the SAO model.

\section{Methodology}

The sample size for this research were 678 undergraduate students. The instruments used namely the Rosenberg Self-Esteem Scale, the Job Search Intensity Scale, and the Career Decision-Making Self-Efficacy Scale. The Rosenberg Self-Esteem Scale-used to measure students' global self-esteem. This instrument is one of the most widely used to measure self-esteem in research settings (Raes \& Gucht, 2009; Emmanuelle, 2009; Pullmann \& Allik, 2008; Salmero-Aro \& Nurmi, 2007). The focuses of this instrument is on people's general feelings toward themselves, without referring to any specific quality or attribute. The original SE has 10-item scale. The items are scored by using a 4-point Likert-type, ranging from 0 (strongly disagree) to 3 (strongly agree). The wordings of half of the items are positively directed and the other half are negatively directed. The Job Search Intensity Scale-is a self-report scale assessing behaviours related to seeking employment. This scale measures the frequency of individuals participation in several job seeking behaviours each week with options ranging from 1 (never or zero times) to 5 (very often, at least ten times). The Career Decision-Making Self-Efficacy Scale-is used to assess career decision-making self-efficacy among respondents. The CDMSE measures confidence in accomplishing career-related tasks. There are 25 items in this instrument which are rated on a 5-point scale, with responses ranging from 0 (no confidence at all) to 4 (complete confidence).

This research was a survey-based type and the recruitment of the participants was based on cluster sampling procedure. This research used the test-retest to determine the reliability of the instrument, and then SEM to test the validity of the constructs. To test the moderating effects based on gender, academic performance, faculty and residential setting based on Self-Action-Outcome (SAO) model, the frequency and percentage distributions of the respondents according to personal characteristics setting are shown below.

Table 1. Respondents' distribution based on gender, academic performance, faculty and residential setting $(\mathrm{N}=$ 678)

\begin{tabular}{cccc}
\hline Respondents' Distribution & Type & Frequency & Percentage \\
\hline \multirow{2}{*}{ Gender } & Male & 404 & 59.4 \\
& Female & 274 & 40.6 \\
Academic & & & \\
Performance & Low $(2.00-2.99)$ & 356 & 52.5 \\
& High (3.00-4.00) & 322 & 47.5 \\
Faculty & FEE & 126 & 18.6 \\
& FMCE & 128 & 18.9 \\
& FICT & 147 & 21.7 \\
& FECE & 142 & 20.9 \\
& FME & 135 & 19.9 \\
\hline
\end{tabular}




\begin{tabular}{cccc}
\hline Respondents' Distribution & Type & Frequency & Percentage \\
\hline \multirow{2}{*}{ Residential Setting } & & & \\
& Rural & 402 & 59.3 \\
& Urban & 276 & 40.7 \\
\hline
\end{tabular}

Note: FEE = 'Faculty of Electrical Engineering', FMCE = 'Faculty of Manufacturing Engineering', FICT = 'Faculty of Information and Communication Technology', FECE = 'Faculty of Electronic and Computer Engineering', $\mathrm{FME}=$ 'Faculty of Mechanical Engineering'

\section{Results}

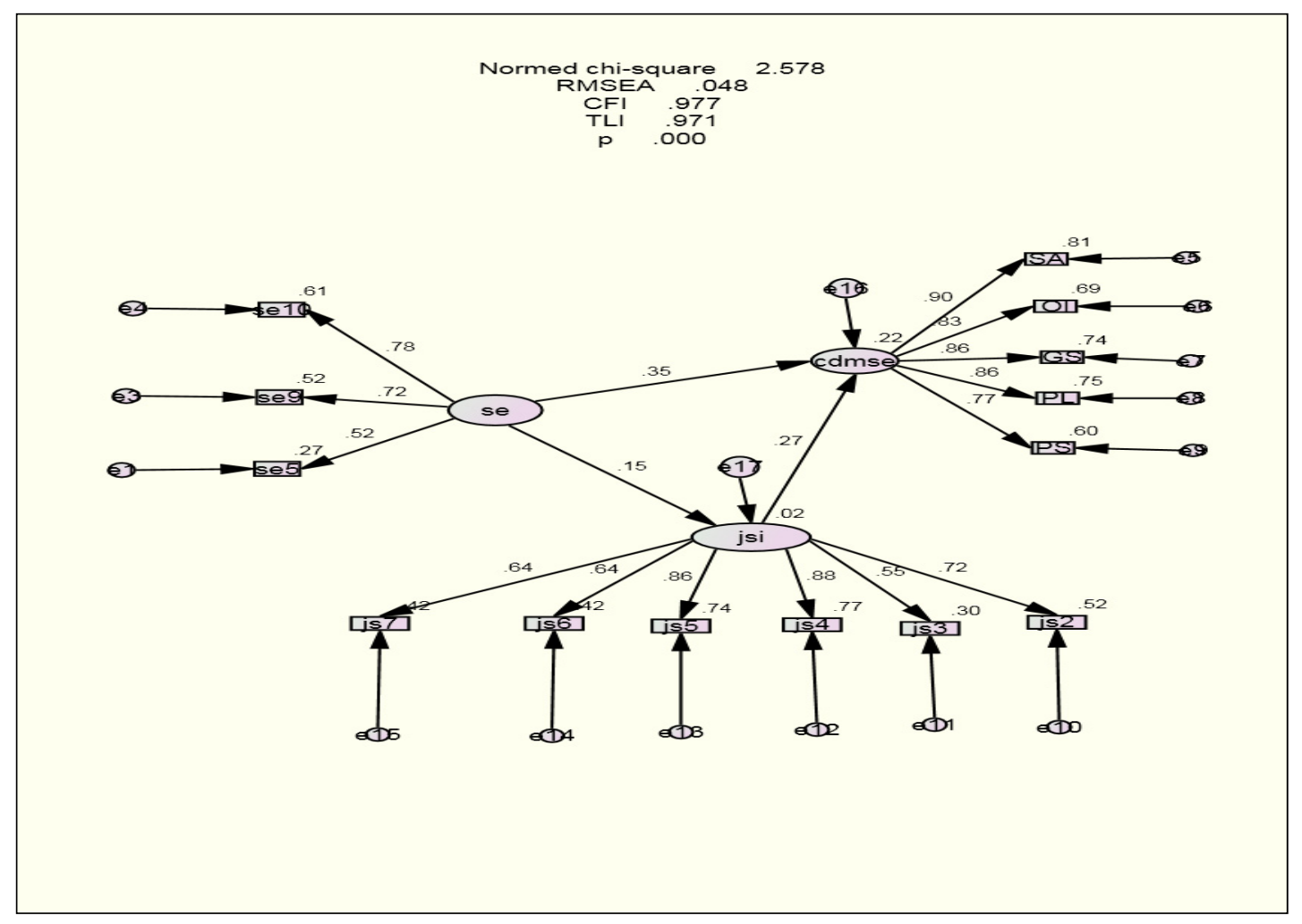

Figure 1. Self-Action-Outcome (SAO) model of self-esteem, job-search intensity and career decision-making self-efficacy

Figure 1 presents the empirical results of hypothesized structural relationship model of self-esteem, job-search intensity, and career decision-making self-efficacy (SAO model). The overall fit of the model was adequate with $\mathrm{CFI}=.977, \mathrm{TLI}=.971$ and $\mathrm{RMSEA}=.048$. The statistics indicate that the parameters were free from offending estimates, ranging from .52 to .90 . The CFI (.977) and TLI (.971) fit indicators exceeded the threshold of .90, indicating a very good fit. The root mean square error of approximation $(\mathrm{RMSEA}=.048$ ) has met the cut-off point requirement for a reasonable error of approximation. The normed chi-square of 2.578 for a good fit is also met (Byrne, 2010). The final fit index indicates that the test failed to reject the hypothesized model. Therefore, there is strong significant relationship with value of .35 between self-esteem and career decision-making self-efficacy among undergraduate students. There is significant relationship with value of .27 between job-search intensity and career decision-making self-efficacy among undergraduate students and there is significant relationship but rather weak with value of .15 between self-esteem and job-search intensity among undergraduate students. As such, the researcher concludes the Figure 1 to be the validated structural equation model. Therefore, a self-action-outcome model is developed as shown in Figure 1.

To answer hypothesis 1, 2, 3 and 4 in this multi-group analysis, hypothesized SAO model is constructed to test the adequacy of the model based on a four step procedure (Hair et al., 2010). The four steps involved are: Step 1 - to test the adequacy of the hypothesized SAO model on pooled data. Step 2 - to test the hypothesized SAO model for each group separately. Step 3 - to test the structural equivalence (configural) invariance across samples 
simultaneously-creation of baseline model. Step 4 - to test for metric invariance, at varying degree of stringency: i) equality of loadings, ii) equality of variances \& covariances. Findings for these hypotheses as shown in Table 2.

Table 2. Summarized results of multiple group modelling - gender, academic performance, faculty and residential setting invariant

\begin{tabular}{|c|c|c|c|c|}
\hline & $\chi^{2}$ & $d f$ & $\chi^{2}$ Change & Critical-Value \\
\hline \multicolumn{5}{|l|}{ Gender } \\
\hline Baseline & 309.43 & 148 & 17.80 & 36.12 \\
\hline Constrained & 327.23 & 162 & & \\
\hline \multicolumn{5}{|l|}{ Academic Performance } \\
\hline Baseline & 305.01 & 148 & 18.79 & 36.12 \\
\hline Constrained & 323.79 & 162 & & \\
\hline \multicolumn{5}{|l|}{ Faculty } \\
\hline Baseline & 526.59 & 370 & 90.08 & 94.47 \\
\hline Constrained & 584.18 & 414 & & \\
\hline \multicolumn{5}{|l|}{ Residential Setting } \\
\hline Baseline & 263.31 & 148 & 13.25 & 36.12 \\
\hline Constrained & 276.56 & 162 & & \\
\hline
\end{tabular}

*Statistically significant at $p<.05$

The factor loadings for the tested baseline model for gender in the male and female groups' model are substantially significant with the chi-square $\left(\chi^{2}\right)$ of 309.432 with $d f$ of 148 . The factor loadings for tested constrained model in the male and female groups' model are substantially significant with the chi-square $\left(\chi^{2}\right)$ of 327.230 with $d f$ of 162 .

The factor loadings for the tested baseline model for academic performance in the low academic performance and high academic performance groups' model are substantially significant with the chi-square $\left(\chi^{2}\right)$ of 305.006 with $d f$ of 148. The factor loadings for tested constrained model in the low academic performance and high academic performance groups' model are substantially significant with the chi-square $\left(\chi^{2}\right)$ of 323.793 with $d f$ of 162.

The factor loadings for the tested baseline model for faculties in the FEE, FMCE, FICT, FECE and FME groups' model are substantially significant with the 'chi-square' $\left(\chi^{2}\right)$ of 606.670 with $d f$ of 426 . The factor loadings for tested constrained model in the FEE, FMCE, FICT, FECE and FME groups' model are substantially significant with the 'chi-square' $\left(\chi^{2}\right)$ of 606.670 with $d f$ of 426 .

The factor loadings for the tested baseline model for residential setting in the rural and urban groups' model are substantially significant with the 'chi-square' $\left(\chi^{2}\right)$ of 263.308 with $d f$ of 148 . The factor loadings for tested constrained model in the rural and urban groups' model are substantially significant with the chi-square $\left(\chi^{2}\right)$ of 276.564 with $d f$ of 162 .

Table 2 shows the result that critical values ( $\chi 2$ value table) more than $\chi^{2}$ change means that the hypothesized $\mathrm{SAO}$ model is a good model. The result shows that gender, academic performance, faculty and residential setting did not moderate the causal structure of the hypothesized SAO model among graduating students.

\section{Discussion}

The summarized results of multiple groups modelling from Table 2 show that the difference in the chi-square values between the baseline model and the constrained model do not produce a poorer-fit model. The path coefficients do not vary significantly across gender (male and female), academic performance (high academic and low academic), faculty (FEE, FMCE, FICT, FECE, and FME) and residential setting (rural and urban). It can be concluded that gender, academic performance, faculty and residential setting are not moderating variables to influence the SAO model.

Gender chi-square critical value (36.12) bigger than chi-square change (17.80) means that the hypothesized model (SAO model) is a good model. In fact, gender does not mediate the SAO model which is in contrast to the finding from other scholars which found that gender mediated self-esteem (Duran \& Tezer, 2009, Karagozoglu et al. 2008, Sherina et al. 2008, Kundu \& Rani, 2007, Aricak, 2007, and McMullin \& Cairney, 2004). Another 
study done by Mau \& Kopischke (2001) reported that gender influenced job-search intensity, and also career decision-making (Melati, 2006; Gushue, 2006; Foster, 2005).

Similarly, the finding of this research supports other findings (Norida, Tajudin, \& Kalthom, 2012; Feinstein-messinger, 2007; Aleidan, 2002; Chung, 2002) in which gender did not mediate career decision-making. More importantly, the present research finds that gender does not influence students' self-esteem, job-search intensity and career decision-making self-efficacy when all the three variables are combined in a relationship model as an SAO model. It shows that the SAO model is a good fit model and did not mediate by gender. This finding is in contrast to other findings because this research tested the SAO model which included self-esteem, job-search-intensity and career decision-making self-efficacy. Previous researchers tested each variable separately with gender.

Structural invariance across academic performance from this research shows that chi-square critical value (36.12) bigger than chi-square change (18.79) means that academic performance does not mediate the SAO model. Results from previous researchers (Pullmann \& Allik, 2008; Nurzarimah, 2002; Siti Mariam, 2006) found that academic achievement mediated students' self-esteem which is in contrast to the findings of this research. However, the result from this research is congruent with the results of the study done by Van der Klaauw and Van Vuuren (2010) which found that job-search effort was not influenced by academic achievements of students when entering the labour market. Indeed, academic achievement does not mediate job-search intensity among students. More importantly, the present research finds that academic performance does not influence students' self-esteem, job-search intensity and career decision-making self-efficacy when all the three variables are combined in a relationship model as an SAO model. It shows that the SAO model is a good fit model and was not mediated by the academic performance.

The invariance test across the faculty groups also shows that the chi-square critical value (94.47) is more than chi-square change (90.08) which means that faculties do not mediate the SAO model. The present finding is in contrast to the finding by Aricak (2007), which finds that self-esteem differ among students from different departments. This means that different departments influence the self-esteem among students. With the finding of the present research shows that, self-esteem, job-search intensity and career decision-making self-efficacy model do not mediate among the students of the different faculties. Regardless of which faculty students come from, the SAO model results have validated a good-fit.

Finally, the invariance test across students who come from rural or urban area (residential setting) shows that chi-square critical value (36.12) bigger than chi-square change (13.25) means that the residential settings do not mediate the SAO model. The present finding supports previous finding (McMullin \& Cairney, 2004) which found that social class did not influence levels of self-esteem for young men or women. The finding from the current research shows that residential setting does not mediate self-esteem, job-search intensity, and career decision-making self-efficacy model among graduating university students. It shows that regardless where the graduating university students came from, this did not influence the SAO model. The finding of the current research also shows that the SAO model results have validated a good-fit.

In conclusion, based on the results of multiple groups modelling across gender (male and female), academic performance (high academic and low academic), faculties (FEE, FMCE, FICT, FECE, and FME) and residential setting (rural and urban), it can be concluded that the hypothesized SAO model results have validated a good-fit. Gender, academic performance, faculty and residential setting are not moderating variables to influence the SAO model.

The findings of the present research have broadened the knowledge on relationship among self-esteem, job-search intensity, and career decision-making self-efficacy among undergraduate students. The results indicate that self-esteem is strongly related to career decision-making self-efficacy among undergraduate students. The self-esteem and career decision-making self-efficacy have a positive relationship in the full-fledged structural equation modelling model. Result of this finding shows that if self-esteem increases the career decision-making self-efficacy also increases among undergraduate students. Therefore, it is pertinent for the undergraduate students to build up their self-esteem in order to make them more confident in preparing themselves for career. Individuals with high self-esteem are generally confident of themselves, self-directed, decisive, loving and lovable, eager to express idea, assertive and get along well with others. They also accept themselves unconditionally and are willing to take calculated risks (Ranjit, 2009).

The results indicate that the job-search intensity have a significant relationship with career decision-making self-efficacy. Result of this finding shows that if job-search intensity increases the career decision-making self-efficacy also increases among undergraduate students. Therefore, it is important for the undergraduate 
students to actively involve with job search behaviour in order to make them more confident in preparing themselves for career. The finding of the research affirms the study done by others researchers (Kanfer, Wanberg, \& Kantrowitz, 2001; Salmero-Aro \& Nurmi, 2007; Saks, 2005; Tziner, Vered, \& Ophir, 2004; Saks \& Ashforth, 2000) and shows that there is a significant relationship between job-search intensity and career decision-making self-efficacy.

The results also indicate that self-esteem have a significant relationship with the job-search intensity. Therefore, it is important for the undergraduate students to build up their self-esteem in order to make them have more productive behaviour. Individual with low self-esteem will go for conventional jobs compared to individuals with high self-esteem who dare to take more risks in job selection (Ranjit, 2009). High self-esteemed individuals are more successful in their job searches compared to low self-esteemed individuals.

\section{Conclusion}

The research has resulted in highlighting several invaluable contributions and implications for professionals, and particularly practitioners. The main practical contribution of this study for practitioners is to bring to their attention the relationship among self-esteem, job-search intensity and career decision-making self-efficacy. The results are useful in helping the transition process of students from university to work. Such information could lead to an improvement in planning and policy-making for the development of a more effective and efficient counselling and career guidance system in the university settings. Practices of counselling by Guidance Counsellors are to provide guidance to students in preparing for their working life. This includes the development of attitude, beliefs, and students' psychological development.

\section{Acknowledgements}

The authors would like to thank the participating students for their co-operations. We would also like to express our gratitude to Universiti Teknikal Malaysia Melaka for supporting these research activities.

\section{References}

Abdullah N., Ninggal, M. T., \& Husain, K. (2012). Model of self-esteem, job-search intensity and career decision-making self-efficacy for graduating students. Proceeding of International Conference on Science, technology and Social Science (ICSTSS 2012), 20- 22 November 2012. Universiti Teknologi MARA, Kuantan, Pahang, Malaysia.

Aharon, T., Efrat, V., \& Limor, O. (2004). Predictors of job-search intensity among college graduates. Journal of Career Assessment, 12(3), 332-344. http://dx.doi.org/10.1177/1069072704266677

Aleidan, M. A. (2002). Career decision-making self-efficacy, occupational preferences, and gender: A study of undergraduate students at King Saud University in Riyadh, Saudi Arabia (Unpublished doctoral thesis). Florida Atlantic University, USA.

Anis, M. N. (2006). Too much job-hopping bad for career. Retrieved May 15, 2008, from http://www.star-jobs.com/news/story.asp?file=/2006/3/15/starjobs/13663628\&sec=starjobs

Aricak, O. T. (2007). The investigation of Turkish university students' vocational self-esteem levels within different academic departments. Retrieved July, 1, 2009, from http://www.eric.ed.gov/ERICDocs/data/ ericdocs2sq1/content_-storage_01/0000019b/80/38/e5/60.pdf

Barry Chung, Y. (2002). Career decision-making self-efficacy and career commitment: Gender and ethnic differences among college students. Journal of Career Development, 28(4), 277-284. http://dx.doi.org/10. $1177 / 089484530202800404$

Baumeister, R. F., Campbell, J. D., Krueger, J. I., \& Vohs, K. D. (2003). Does high self-esteem cause better performance, interpersonal success, happiness, or healthier lifestyles? Psychological Science in the Public Interest, 4, 1-44. http://dx.doi.org/10.1111/1529-1006.01431

Betz, N. E. (2004). Contributions of self-efficacy theory to career counselling: a personal perspective. The Career Development Quarterly, 62, 340-353. http://dx.doi.org/10.1002/j.2161-0045.2004.tb00950.x

Brown, D. J., Cober, R. T., Kane, K., Levy, P. E., \& Shalhoop, J. (2006). Proactive personality and the successful job-search: A field investigation with college graduates. Journal of Applied Psychology, 91(3), 717-726. http://dx.doi.org/10.1037/0021-9010.91.3.717

Byrne, B. M. (2010). Structural equation modelling with AMOS. Basic concepts, applications, and programming (2nd ed.). New York: Routledge.

Cote. S., Saks, A. M., \& Zikic, J. (2006). Trait affect and job-search outcomes. Journal of Vocational Behavior, 
68, 233-252. http://dx.doi.org/10.1016/j.jvb.2005.08.001.

Crespin, C. A. (2006). Contributors to college women's career decision-making self-efficacy: support, barriers, and coping (Unpublished doctoral thesis). Fordham University, USA.

Crocker, J. (2004). Self-esteem in adulthood. International Encyclopaedia of the Social \& Behavioral Sciences, $13822-13826$.

Crossley, C. D., \& Stanton, J. M. (2005). Negative affect and job-search: Further examination of the reverse causation hypothesis. Journal of Vocational Behavior, 66, 549-560. http://dx.doi.org/10.1016/j.jvb.2004. 05.002 .

Duran, N. O., \& Tezer, E. (2009). Wellness and self-esteem among Turkish university students. International Journal for the Advancement of Counselling, 31(1), 32-44. http://dx.doi.org/10.1007/s10447-008-9066-9.

Emmanuelle, V. (2009). Inter-relationships among attachment to mother and father, self-esteem, and career indecision. Article in Press. Journal of Vocational Behavior. http://dx.doi.org/10.1016/j.jvb.2009.04.007.

Ennis, K. E. (2006). The relationships among hope, family functioning, career barriers, career-decision-making self-efficacy, and involvement in a school to-work program (Unpublished doctoral thesis). New Mexico State University, USA.

Feinstein-Messinger, G. (2007). The nexus among career decision self-efficacy, parental relationship factors, and career indecision among college students from different ethnic and racial groups (Unpublished doctoral thesis). City University of New York. New York, USA

Foster, D. B. (2005). Students and their careers: A study of career decision-making self-efficacy and vocationalism in undergraduate students (Unpublished doctoral thesis). Queens University Belfast. United Kingdom.

Gushue, G. V. (2006). The relationship of ethnic identity, career decision-making behavior of working class students. Do economic barriers stand in the way? Journal of European Industrial Training, 32(7), 492-509. http://dx.doi.org/10.1016/j.jvb.2005.03.002

Hair, J. F., Jr., Black, W. C., Babin, B. J., \& Anderson, R. E. (2010). Multivariate Data Analysis (7th ed.) Upper Saddle, New Jersey: Pearson Prentice Hall.

Jamil, N. (2002). The study of self-esteem and academic self-image of the 2nd and 4th year TESL students in Universiti Teknologi Malaysia (Unpublished master thesis). Universiti Teknologi Malaysia, Skudai.

Kanfer, R., Wanberg, C. R., \& Kantrowitz, T. M. (2001). Job-search and employment: A personality-motivational analysis and meta-analytic review. Journal of Applied Psychology, 86, 837-855. http://dx.doi.org/10.1037/ 0021-9010.86.5.837

Karagozoglu, S., Kahve, E., Koc, O., \& Adamisoglu, D. (2008). Self-esteem and assertiveness of final year Turkish university students. Nurse Education Today, 28, 641-649. http://dx.doi.org/10.1016/j.nedt.2007. 09.010

Kundu, S, C., \& Rani, S. (2007). Human resources' self-esteem across gender and categories: A study. Industrial Management and Data Systems, 107(9), 1366-1390. http://dx.doi.org/10.1108/02635570710834018

Lazaroo, S. (2008). Carve your niche at Naza. GRADUAN. Careers \& employment for Malaysian fresh graduates 2008 (pp. 151-153). Ampang, Selangor: BIZ Connexion Sdn Bhd.

Mau, W. C., \& Kopischke, A. (2001). Job-search methods, job-search outcomes, and job satisfaction of college graduates: a comparison of race and sex. Journal of Employment Counselling, 38, 141-149. http://dx.doi.org/10.1002/j.2161-1920.2001.tb00496.x

McMullin, J. A., \& Cairney, J. (2004). Self-esteem and the intersection of age, class, and gender. Journal of Aging Studies, 18, 75-90. http://dx.doi.org/10.1016/j.jaging.2003.09.006

Mohamad, S. M. (2006). Hubungan penghargaan kendiri dengan pencapaian akademik pelajar tahun akhir jurusan kimia di Fakulti Pendidikan (Unpublished master thesis). Universiti Teknologi Malaysia, Skudai.

Montgomery, J. K. (2006). The prediction of career decision-making self-efficacy from Black and White racial identity attitudes (Unpublished doctoral thesis). Louisiana Tech University, USA.

NICHE. (2009). Higher Education in the Learning Society (The Dearing Report), London, 1997, (paragraph 4.22). Retrieved February 10, 2009, from http://bei.leeds.ac.uk/Partners/NICHE/ 
Omar, Z. (2008). The Ideal Graduate. GRADUAN. Careers \& employment for Malaysian fresh graduates 2008 (pp. 41-43). Ampang, Selangor: BIZ Connexion Sdn Bhd.

Pullmann, H., \& Allik, J. (2008). Relations of academic and general self-esteem to school achievement. Personality and Individual Differences, 45, 559-564. http://dx.doi.org/10.1016/j.paid.2008.06.017

Raes, F., \& Gucht, D. V. (2009). Paranoia and instability of self-esteem in adolescents. Personality and Individual Differences, 47, 928-932. http://dx.doi.org/10.1016/j.paid.2009.07.017

Ranjit, S. M. (2009). Make yourself employable. How graduates can hit the ground running. Kuala Lumpur: TQM Consultants Sdn. Bhd.

Rowland, K. D. (2004). Career decision-making skills of high school students in the Bahamas. Journal of Career Development, 31(1), 1-13. http://dx.doi.org/10.1177/089484530403100101.

Saks, A. M. (2005). Job-search success: A review and integration of predictors, behaviors, and outcomes. In S. D. Brown, \& R. W. Lent (Eds.), Career Development and Counselling. Putting theory and research to work (pp. 155-179). Canada: John Wiley \& Sons, Inc.

Saks, A. M., \& Ashforth, B. E. (2000). Change in job-search behaviors and employment outcomes. Journal of Vocational Behavior, 56, 277-287. http://dx.doi.org/10.1006/jvbe.1999.1714.

Salmero-Aro, K., \& Nurmi, J. E. (2007). Self-esteem during university studies predicts career characteristics 10 years later. Journal of Vocational Behavior, 70, 463-477. http://dx.doi.org/10.1016/j.jvb.2007.01.006.

Schaufelli, W. B., Martinez, I. M., Marques Pinto, A., Salanova, M., \& Bakker, A. B. (2002). Burnout and engagement in university students: A cross-national study. Journal of Cross-Cultural Psychology, 33, 464-481. http://dx.doi.org/10.1177/0022022102033005003.

Sherina, M. S., Rampal, L., Loh, J. W., Chan, C. L., Teh, P. C., \& Tan, P. O. (2008). Self-esteem and its associated factors among secondary school students in Klang District, Selangor. Medical Journal of Malaysia, 63(1), 26-30.

Sumari, M. (2006). Family functioning and career decision-making self-efficacy: A study of first year Malaysian undergraduate students (Unpublished doctoral thesis). Western Michigan University, Kalamazoo, Michigan, USA.

Swanson, J. L., \& D'Achiardi, C. (2005). Beyond interest, needs/values, and abilities: assessing other important career constructs over the life span. In S. D. Brown, \& R. W. Lent (Eds.), Career Development and Counseling. Putting theory and research to work (pp. 353-381). Canada: John Wiley \& Sons, Inc.

Tziner, A., Vered, E., \& Ophir, L. (2007). Predictors of job-search intensity among college graduates. Journal of Career Assessment, 12(3), 332-344. http://dx.doi.org/10.1177/1069072704266677

UNESCO Report 2007 - Report of meeting on a multi-stakeholder approach to address graduate (un)employment, 16 - 17 November 2006, Bangkok, Thailand. Retrieved March 20, 2009, from http://unesdoc.unesco.org/images/0015/001529//152959e.pdf

van der Klaauw, B., \& van Vuuren, A. (2010). Job-search and academic achievement. European Economic Review, 54(2), 294-316. http://dx.doi.org/10.1016/j.euroecorev.2009.07.001

Van Hooft, E. A. J., Born, M. P., Taris, T. W., \& Flier, H. V. D. (2004). Job-search and the theory of planned behaviour: Minority-majority group differences in the Netherlands. Journal of Vocational Behavior, 65, 366-390. http://dx.doi.org/10.1016/j.jvb.2003.09.001

Zunker, V. G. (2006). Career counselling. A holistic approach (7th ed.). Belmont, CA: Thomson Brooks/Cole.

\section{Copyrights}

Copyright for this article is retained by the author(s), with first publication rights granted to the journal.

This is an open-access article distributed under the terms and conditions of the Creative Commons Attribution license (http://creativecommons.org/licenses/by/3.0/). 